Personalidade Acadêmica Homenageada:

Augustus B. Cochran III (Agnes Scott College)

\title{
CLANDESTINO SEM PAPEL: AS IMPLICAÇÕES SOCIAIS E LEGAIS DO NÃO ACOLHIMENTO DOS REFUGIADOS VENEZUELANOS NO BRASIL
}

\section{CLAPESTINE WITHOUT PAPER: THE SOCIAL AND LEGAL IMPLICATIONS OF NOT ACCOMPLISHING VENEZUELAN REFUGEES IN BRAZIL}

DAVI LUIZ GOMES

Graduando em Direito, modalidade Integral- Escola Superior Dom Helder CâmaraESDHC-Belo Horizonte- MG E-mail: davilgomes38@gmail.com.

LARA MIRANDA CALOY Graduanda em Direito, modalidade Integral- Escola Superior Dom Helder CâmaraESDHC-Belo Horizonte- MG E-mail:Iaracaloy@hotmail.com.

CAIO AUGUSTO SOUZA LARA Mestre e Doutor em Direito pela Faculdade de Direito da Universidade Federal de Minas Gerais - UFMG. Professor da Escola Superior Dom Helder Câmara. Pesquisador Associado ao Programa RECAJ-UFMG - Acesso à Justiça e Solução de Conflitos. Secretário de Comunicação do Conselho Nacional de Pesquisa e Pósgraduação em Direito - CONPEDI. Belo Horizonte-MG. E-mail: caiolarabh@yahoo.com.br 
Personalidade Acadêmica Homenageada:

Augustus B. Cochran III (Agnes Scott College)

\section{RESUMO}

O tema-problema da pesquisa que se pretende desenvolver é o abandono por parte do Estado em relação aos refugiados venezuelanos, pela negação do visto. Em decorrência a este fenômeno, o número de refugiados que chega ao Estado de Roraima tem crescido de forma vertiginosa, o que causa receio na população local, como é sabido e ao mesmo tempo uma sobrecarga burocrática no estado para a legalização e emissão de vistos para todos os indivíduos como explicitado na Lei do Migrante, número 13.445 (BRASIL, 2017). Ademais, o atual contato com os refugiados por todo território brasileiro tem gerado um sentimento de aversão, principalmente no âmbito econômico, haja vista que a nação está em um momento de recessão e com isso, a dificuldade de emprego fixo e com carteira assinada, a deficiência ainda maior dos serviços públicos tem sido uma constante na vida dos nacionais e em suas mentalidades os imigrantes acirraram essa disputa. Os nativos sentem insegurança em relação aos refugiados, que no senso comum do Brasil são vistos como perigosos e criminosos. São esses medos gerados pelo preconceito e pela incapacidade do Estado em reconhecer e integrar os refugiados que acarretam em atos cruéis como a destruição de acampamentos improvisados de venezuelanos e a expulsão do país destes pelos brasileiros, ações que ferem os direitos individuais dos imigrantes. Dessa forma, o problema objeto da investigação científica proposta é: quais as principais repercussões jurídicas das violações da emissão de visto aos refugiados? A partir das reflexões preliminares sobre o tema, é possível afirmar inicialmente que a pesquisa busca entender formas que possam assegurar os plenos direitos humanos aos dos refugiados venezuelanos, a partir da regulamentação dos documentos. Além disso, visa buscar meios de se integrar socialmente esses imigrantes em solo brasileiro e dessa forma, tentar coibir o sentimento de xenofobia, que infelizmente já é uma realidade social. Sendo assim, o objetivo geral do trabalho é analisar as dificuldades em garantir os direitos dos venezuelanos sem visto, os quais estão inseridos na atual crise humanitária. E, outrossim como objetivos específicos do trabalho, enumeram-se os seguintes: levantar as privações que os venezuelanos sofrem atualmente, tais como fome, falta de trabalho e moradia; constatar os fatores que levam os 
Personalidade Acadêmica Homenageada:

Augustus B. Cochran III (Agnes Scott College)

venezuelanos a imigração; refletir as condições governamentais da Venezuela atual; analisar a influência da potência americana no cenário de crise venezuelano; investigar os motivos da ajuda humanitária não estar se concretizando, definindo as causas para essa realidade; avaliar a posição do governo brasileiro perante essa realidade de crise humanitária sofrida na Venezuela; levantar os requisitos para a emissão de visto aos refugiados venezuelanos em território brasileiro; analisar o respaldo jurídico brasileiro que garanta os direitos humanos dos refugiados, bem como analisar as causas para o crescente sentimento xenofóbico no atual cenário brasileiro. Além desse contexto, a pesquisa que se propõe pertence à vertente metodológica jurídico-sociológica. No tocante ao tipo de investigação, foi escolhido, na classificação de Witker (1985) e Gustin (2010), o tipo jurídico-projetivo. O raciocínio desenvolvido na pesquisa será predominantemente dialético. De acordo com a técnica de análise de conteúdo, afirma-se que se trata de uma pesquisa teórica, o que será possível a partir da análise de conteúdo dos textos doutrinários, normas e demais dados colhidos na pesquisa. Como conclusão parcial do trabalho, tem-se que as principais implicações na vida dos refugiados venezuelanos, como a não asseguração de seus plenos direitos e a xenofobia são resultados da falibilidade do Estado brasileiro de integrá-los à sociedade.

PALAVRAS-CHAVES: Direitos Humanos; Refugiados; Visto; Venezuelanos.

\section{REFERÊNCIAS}

ARENDT, Hannah. As Origens do Totalitarismo. São Paulo: Companhia das Letras, 2012.

. Nós, os refugiados. Covilhã: Lusosofia, 2013.

BARRETO, Luiz Paulo Teles Ferreira (org). Refúgio no Brasil. Brasília: 2010.

BAUMAN, Zygmunt. Estranhos à nossa porta. Rio de Janeiro: Zahar, 2017. 
Personalidade Acadêmica Homenageada:

Augustus B. Cochran III (Agnes Scott College)

BRASIL. Lei 13445, de 24 maio de 2017. Institui a lei de imigração. Disponível em: http://www.planalto.gov.br/ccivil_03/_ato2015-2018/2017/lei//13445.htm. Acesso em: 10 de maio 2019.

. Ministério da Justiça. Secretaria Nacional da Justiça. Refúgio em números. Brasília: 2018, p.30.

COSTA, Patrícia Ayub. The challenge of human rights effectiveness in the context of economic globalization: what is the work of the united nations? Revista JurídicaUNICURITIBA. V. 1, № 54, p. 97- 115. 2019. Disponível em: http://revista.unicuritiba.edu.br/index.php/RevJur/article/view/3302. Acesso em: 20 de maio 2019.

DIAS, Marina. Discurso de Trump sobre intervir na Venezuela é 'figura retórica', diz Mourão. Portal Folha de São Paulo. 06 abr. 2019. Disponível em: https://www1.folha.uol.com.br/mundo/2019/04/discurso-de-trump-sobre-intervir-navenezuela-e-figura-de-retorica-diz-mourao.shtml. Acesso em: 30 abr. 2019.

GUSTIN, Miracy Barbosa de Sousa; DIAS, Maria Tereza Fonseca. (Re)pensando a pesquisa jurídica: teoria e prática. 3ª . ed. Belo Horizonte: Del Rey, 2010.

KANT, Immanuel. A Paz Perpétua e outros Opúsculos. Lisboa: Edições 70, 1995.

MENDONÇA, Heloísa. O "monstro da xenofobia" ronda a porta de entrada de venezuelanos no Brasil. Portal El País. 27 ago. 2018. Disponível em: https://brasil.elpais.com/brasil/2018/08/17/politica/1534459908_846691.html. Acesso em: 30 abr. 2019.

MESQUITA, Lígia; CORAZZA, Felipe. Crise na Venezuela: o que levou o país vizinho ao colapso econômico e à maior de sua história. Portal BBC News Brasil. 01 mar. 2019. Disponível em: https://www.bbc.com/portuguese/internacional-45909515. Acesso em: 25 abr. 2019.

ORGANIZAÇÃO DAS NAÇÕES UNIDAS. Alto Comissariado das Nações Unidas para Refugiados. https://www.acnur.org/portugues/.

WITKER, Jorge. Como elaborar uma tesis en derecho: pautas metodológicas y técnicas para el estudiante o investigador del derecho. Madrid: Civitas, 1985. 